\title{
DỨcin
}

Technological University Dublin ARROW@TU Dublin

\section{Rethinking zoning for people: Utilizing the concept of the village}

\author{
Kevin Leyden \\ National University of Ireland, Galway \\ Lorraine D'Arcy \\ Technological University Dublin, lorraine.darcy@tudublin.ie
}

Follow this and additional works at: https://arrow.tudublin.ie/beschspoth

Part of the Civil and Environmental Engineering Commons

\section{Recommended Citation}

Leyden, Kevin \& D'Arcy, Lorraine. (2018). Rethinking Zoning for People: Utilizing the Concept of the Village. 10.1007/978-3-319-66869-7_4.

This Book Chapter is brought to you for free and open access by the School of Transport Engineering, Environment and Planning at ARROW@TU Dublin. It has been accepted for inclusion in Other by an authorized administrator of ARROW@TU Dublin. For more information, please contact arrow.admin@tudublin.ie, aisling.coyne@tudublin.ie, gerard.connolly@tudublin.ie.

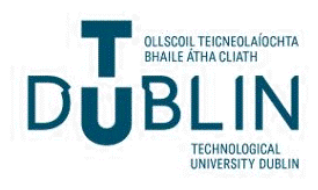


See discussions, stats, and author profiles for this publication at: https://www.researchgate.net/publication/320235874

\section{Rethinking Zoning for People: Utilizing the Concept of the Village}

Chapter · January 2018

DOI: 10.1007/978-3-319-66869-7_4

CITATIONS

2

2 authors:

Kevin M Leyden

National University of Ireland, Galway

51 PUBLICATIONS 2,939 CITATIONS

SEE PROFILE

Some of the authors of this publication are also working on these related projects:

Walkability App View project

GOGREEN ROUTES: GO GREEN Resilient Optimal Urban natural, Technological and Environmental Solutions View project

\section{READS}

185

Lorraine D'Arcy

TU Dublin

4 PUBLICATIONS 5 CITATIONS

SEE PROFILE 


\title{
Rethinking Zoning for People: Utilizing the Concept of the Village
}

\author{
Kevin M. Leyden and Lorraine Fitzsimons D'Arcy
}

\begin{abstract}
In this chapter, we propose it is time to re-think and re-imagine how we approach zoning. This is especially true for suburban developments. Today, especially in the United States, zoning in suburban areas is being used to segregate and separate the component parts of our communities into distinct zones which are spread out geographically and in most cases require the daily use of an automobile. The negative consequences of this form of development for health, community and the environment are discussed. Using a study of neighborhoods in Dublin, Ireland and its suburbs we examine how professionals and the public view the places they live and connect these perspectives to the manner in which zoning has changed over the course of the twentieth century. Insights from these professionals and the public lead us to propose that planners, engineers and developers be expected to think more about the kinds of walkable village neighborhoods that people seem to be drawn to almost instinctively. We urge that zoning laws be re-purposed to enable the building of communities that people prefer to live in.
\end{abstract}

\section{Introduction}

Zoning ordinances were originally well intended. In the name of health, access to light and clean air and water and to deter overcrowding, zoning laws attempted to bring regularity and promote liveability in cities. Urban residents and business wanted the peace of mind that went with knowing that certain uses such as horse livery stables, tanners, factories, and meatpacking facilities would be restricted near the places they worked or lived. Such zoning laws also addressed matters of density

\footnotetext{
K.M. Leyden, Ph.D. ( $\square)$

Professor of Political Science \& Public Policy, School of Political Science \& Sociology,

National University of Ireland, Galway, Ireland

e-mail: kevin.leyden@nuigalway.ie

L. Fitzsimons D'Arcy, Ph.D.

School of Civil and Structural Engineering, College of Engineering and Built Environment,

Dublin Institute of Technology, Dublin, Ireland

e-mail: Lorraine.darcy@dit.ie
}

A. Lehavi (ed.), One Hundred Years of Zoning and the Future of Cities,

DOI 10.1007/978-3-319-66869-7_4 
and the height of buildings so that various types of residential neighborhoods or districts could be planned.

Zoning laws, however, have been used to ill effect at times in certain cities and suburbs. In the United States, prior to World War I, zoning laws were often abused to segregate cities based upon race especially in more Southern cities (Schwieterman \& Caspall, 2006). Later, Northern cities such as Chicago, Detroit, and Los Angeles and their suburbs permitted the use of racial deed restrictions or restrictive covenants which forbid the sale or lease of residential properties to African-Americans and sometimes other minorities (McKenzie, 1994; Schwieterman \& Caspall, 2006). These restrictive covenants were struck down by the U.S. Supreme Court in 1948 and thus could no longer be used as a form of zoning.

But it is not the segregation of people by race or ethnicity that now plagues zoning. It is the segregation of uses. In many countries as diverse as the United States, Ireland, and Israel, for example, contemporary zoning codes narrowly restrict uses into distinctive zones, especially in suburbs and in newer parts of cities. Residential zones of various types are separated from retail zones which are again separated from green space zones or zones for schools. In most cases these zones are separated from each other at some distance and connected by roads creating a need to drive to each with a private vehicle. This type of zoning creates car-dependent suburban sprawl. Although there are important exceptions, most suburban municipalities today use zoning laws that encourage the building of places that are fundamentally different from the types of places that human beings have lived in since we first began to live in permanent settlements.

In this chapter, we propose there is a serious need to rethink zoning practices that emphasize narrowly defined zones based upon uses. We propose that planners should focus far more on placemaking, and the creation of walkable, mixed-use village or neighborhood designs. In planning new places, we need to first conceptualize the sort of places that enable community and are good for people and the environment. Our recommendations are informed by research conducted with both the public and various professionals involved in the planning of Dublin, Ireland and its suburbs.

\section{Pedestrian-Oriented, Mixed-Use Designs vs. Suburban Sprawl: Zoning Makes the Difference}

Whether planned or unplanned villages, towns and later cities were built on the assumption that residents would walk to attain their daily needs. Even when horses were used they typically moved at a walking pace. As a result, urban places were mixed-use. Residents could walk to markets and shops and places of worship and anywhere else they needed to go to meet their daily needs. By design, the places an urban resident needed to go were accessible on foot.

The planning of cities dates back to "at least 2600 BC" in "Mohenjo-Daro and Harappa in the Indus River Valley" (Brown et al., 2009, p. 28). Like the planning 
that would eventually follow in the cities of Babylon, China, Egypt, Greece and Rome, the earliest planned cities tended to be comprised of short blocks of streets that typically followed grid-like patterns (some more winding, others more rectangular) most often surrounding a major market square which included important religious or governmental buildings (Brown et al., 2009).

When New York City adopted its first formal zoning ordinance in 1916, almost nothing about the way New York worked as a city changed. The basic concept of the city as a place that was largely pedestrian-oriented and mixed-use, built upon a grid system of short blocks and streets remained. New York City's public transportation system at the time (e.g., its growing subway system) weaved into this urban form naturally. New York's first zoning ordinance focused mostly upon issues of building height, lot coverages, and setbacks to enable access to light and air. Although specific zones for industrial uses were specified there was little debate by then that such uses should be separated into their own spaces. And by 1916 most Western cities had already recognized the need for regulations, services, and infrastructure to provide city residents with clean water, trash removal, clean streets, sewage and safer housing (Frumkin et al., 2004).

Zoning began to change, however, with the introduction of affordable massproduced automobiles and housing, especially after World War II. The adoption of the car and housing built at a considerable distance from city centers was enabled in the United States by President Eisenhower's Interstate Highway system, which today "includes forty-six thousand miles of roads, built and maintained with tens of billions of federal and state spending" (Glaeser, 2011, p. 173). This coupled with urban crime, poor schools, and racial conflicts that came to a head mainly in cities in the 1960s and 1970s caused millions of Americans to leave cities and to seek what was perceived as a quieter more stable life in suburbs (Baxandall \& Ewen, 2000). Suburban municipalities tended to see density as a problem to be avoided and zoned primarily for low-density development and assumed residents would use cars to move through their communities (Levine, 2010; Southworth \& Ben-Joseph, 1995). From 1950 to 1970 the motor vehicle population in America grew "four times faster than the human one" (Kay, 1997, p. 265).

By the 1980s, especially in the United States, zoning codes in suburbs and in some new cities were creating and enabling a radically different settlement pattern than what had existed for centuries (Duany et al., 2000). The changes were additionally enabled by the legal acceptance of developer-led community or common-interest planning developments (McKenzie, 1994) that put further restrictions on what residents could do with their homes or properties. Suburban and later exurban places were zoned to separate uses into distinctive zones. Zones were thus created for types of residential, types of retail, office parks, areas zoned for schools or places of worship or zoned for parks, among others. Parking requirements were typically attached to every form of land use, meaning that most structures required a great deal of land space to be legal. Indeed, it was as though all the component parts of what used to be considered "the community" were now being zoned and separated geographically at distances that could only be easily traversed by an automobile. And because of a preference for low density housing, usually with big backyards, public transportation 
became too inefficient to work without huge subsidies. The car became the only way to take part in one's community. Therefore, to shop, or go to a restaurant, or to worship or even to enjoy a walk (many suburbs lacked sidewalks) residents would have to own a car or get a lift from someone who did. Children too would be driven by parents to school, or to play or to visit other children. Owning a vehicle out of necessity also facilitated choices to shop outside one's immediate community further removing business and social opportunities away from where people lived. There are of course alternatives to this sort of suburban place, such as those being built and promoted by new urbanists (Duany et al., 2000; Duany \& Talen, 2002; Haas, 2008), but in many jurisdictions notions of living in a walkable suburban village or neighborhood are not only rare, they are not permitted by the zoning ordinance.

Today this restrictive, low-density, spread-out, car-oriented development is called suburban sprawl. It is associated with car-dependency, single family homes on large land plots, shopping malls, large big-box chain stores, large collector schools, massive parking lots, gated communities of various sorts, long commutes and traffic. It is a different type of lifestyle - one enabled by a different interpretation of zoning than the one experienced by those living in cities or towns, older pre-WWII suburbs, or even rural villages. And it is a lifestyle that has been encouraged by zoning regulations not only in the United States but in many suburban areas throughout the world.

There are benefits to suburban living which many people enjoy such as privacy, affordable large homes and good schools in many places (Glaeser, 2011). The vast bulk of empirical research, however, suggests a whole host of unintended consequences to building suburban sprawl and the kind of car-dependent suburban form it is based-upon. For example, researchers have found that car-dependent urban forms contribute to higher emissions of carbon and other forms of air pollution (Kahn, 2007; Glaeser, \& Kahn, 2010; Ewing \& Cervero, 2010). And because residents walk less higher levels of obesity are more likely and people are less likely to meet physical activity targets that are associated with good health (Frank and Engelke 2001; Lovasi et al., 2009; Frank et al., 2006, 2008; De Nazelle et al., 2011; Jackson et al. 2013; Giles-Corti et al., 2016; Lee et al., 2012; U.S. Department of Health and Human Services: Centers for Disease Control and Prevention: National Centre for Chronic Disease Prevention and Health Promotion, 1996; WHO Regional Office for Europe, 2006; Sallis et al., 1998). Others have found that car-dependent designs reduce social activity or social capital (Leyden, 2003), and increase the likelihood of social isolation, depression, and stress from commuting (Frumkin et al., 2004; WHO Regional Office for Europe, 2006; Warburton et al., 2006; Edwards \& Tsouros, 2006; Morris \& Hardman, 1997). Living in such places also increases the likelihood of death or serious injury from car crashes. There were 1.25 million road traffic deaths globally in 2013 (WHO, 2017); about 90 people die each day in the United States from motor vehicle crashes "resulting in the highest death rate among comparison countries" (Centers for Disease Control and Prevention 2017). There are other costs. The need to own at least one car to do almost anything outside the home can place a tremendous financial burden on families (Wickham, 2006). While it may not be a conscious response to these issues, there are places that have seen a price drop in the value of what were desirable suburban locations in 
recent times and an increase in value of what were previously undesirable urban locations (Leinberger, 2012). Indeed, there is growing evidence suggesting when cities improve the quality of urban places they are quite capable of attracting residents across the lifespan and businesses of all types (Florida, 2005, 2010; Goldberg et al., 2012; Hogan et al. 2016; Gallagher, 2017).

As we noted in our introduction, and implied by the purpose of this book, we feel that 100 years is a good time to re-assess the future of zoning. We propose here that planners, engineers, developers and policy-makers need to offer a different land-use model that can compete with those currently on offer; zoning codes need to be reformed to enable a variety of different types of places to be built. Our thoughts about what these new offerings would look like was informed by the Cleaner, Greener, Leaner Study. This was a multi-disciplinary study funded by the Irish Environmental Protection Agency to investigate the influence of neighborhood walkability on residents' physical activity and transport behaviors in the Greater Dublin Area (Fitzsimons D'Arcy, 2013). Although not specifically focused upon zoning, the study's findings provide insight into the way people conceptualize the places they live in or visit. As we shall see below, our focus group and survey participants clearly perceived a fundamental conceptual difference between more walkable and car-dependent neighborhoods in and around Dublin; they also tended to speak more favorably toward more walkable places over car-dependent places when asked in our focus groups.

While the Cleaner, Greener, Leaner Study examined many aspects of neighborhood design and its effects we only focus upon one aspect of the study here: namely how do professionals and the public perceive the difference between more walkable neighborhoods and those that are more car-dependent? We focus upon this aspect of the larger study because we feel it provides important insights into the way zoning laws have affected the way our neighborhoods are perceived and how they function. The Cleaner, Greener, Leaner Study is unique too in that the study specifically asked both professionals and the public about how they perceive and behave in their neighborhoods.

\section{Methods: Two Surveys and Focus Groups}

The Cleaner, Greener, Leaner Study used a mixed methods approach. The study utilized a web-based survey of professionals, a comprehensive population survey of residents living in Dublin and its suburbs, and a series of in-depth focus groups of professionals. Each methods and key findings are discussed below. 


\subsection{The Web-based Survey of Professionals Involved with the Built Environment}

The web-based survey focused upon professionals whose occupations were concerned with the built environment or examining its effects. Opinions of the following occupations - largely living or working in Dublin - were sought: public representatives, public servants from relevant government departments, engineers, transport and spatial planners, urban designers and landscape architects, architects, public health and physical activity promotion professionals, and representatives from relevant advocacy groups. All were familiar with pedestrian infrastructure, planning, streetscapes or walking promotion, yet they came from a range of various disciplines. A number of strategies were used to obtain a sample of these professionals including sign-up sheets at relevant conferences, a systematic identification of relevant government and local authority departments, public representatives, educational institutions, representative bodies and consultancies, to generate a list of individual emails. Recipients were also asked to forward the link to others from their networks who may be interested in completing the survey. It is acknowledged that there is a likely bias in our sample as only those with an interest in the topic were likely to complete the survey. Nonetheless, a diverse, relevant and experienced sample from various professional backgrounds was attained. In all, 219 professionals responded to the web-based survey. The breakdown of the sample is illustrated in Fig. 1. The typical respondent was about 40 years old.

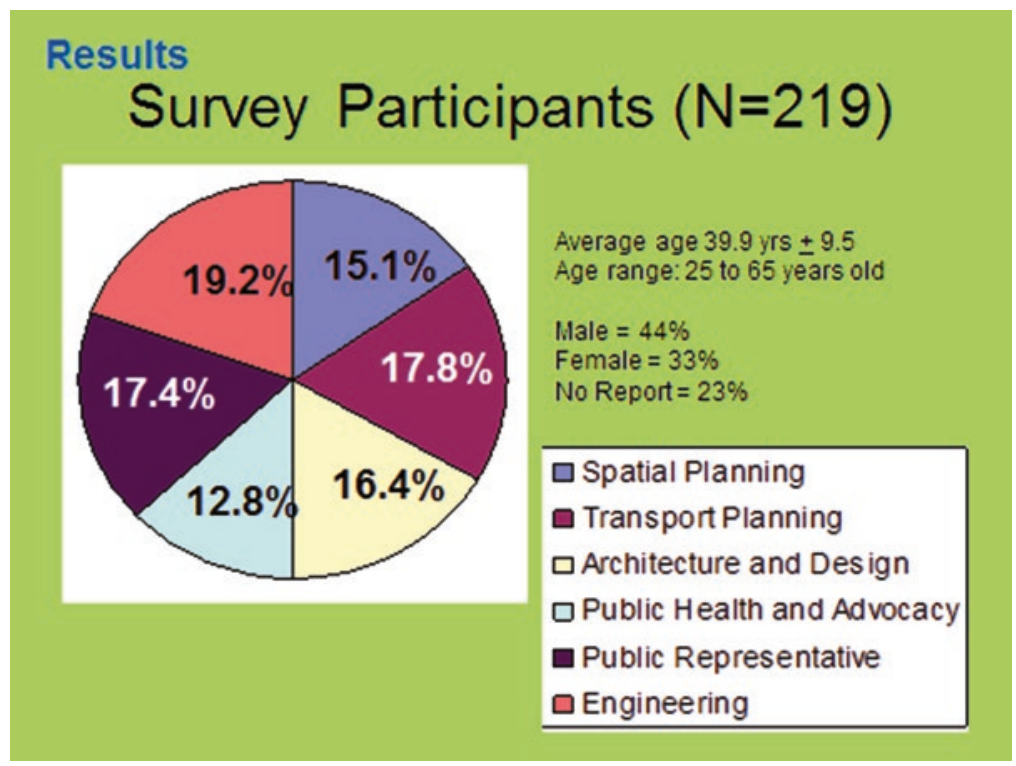

Fig. 1 The Cleaner, Greener, Leaner Study Web-based Survey of Professionals 
Top 5 environmental features positively influencing the walkability of an area:

1. Well maintained footpaths (i.e., sidewalks)

2. Schools, shops, transport stops, recreation facilities and other services within walking distance to people's homes

3. Well-designed pedestrian crossings

4. Access to parks and other green spaces

5. Good street and footpath lighting

Top 5 environmental features negatively influencing the walkability of an area:

1. Above average crime rate

2. Wide roads with multiple lanes of traffic

3. Dirty unkept local area

4. Cul-de-Sacs

5. Long time waiting at pedestrian lights

Fig. 2 Environmental Features associated with Different Types of Neighborhoods $(\mathrm{n}=219)$

Among other questions, respondents were asked to rate the importance of 47 environmental attributes for neighborhood walkability. Each of these 47 attributes was scored from 1 to 5 with 1 being very good for walkability and 5 being very bad for walkability. The list was generated with the diversity of respondents in mind, making reference to a variety of neighborhood features. Fig. 2 lists the mean environmental items most likely to be viewed as very good for walkability and those thought to be the worst for the walkability of a neighborhood or local area.

The environmental items that professionals rated as very important for walkability had to do with mixed-used planning designs and a pedestrian orientation (Fig. 2). Highly walkable places were seen to require access to many destinations "within walking distance to people's homes" such as shops and green spaces and to require pedestrian infrastructure to facilitate walking such as good footpaths or sidewalks, and well-designed pedestrian crossings and lighting. Interestingly the kinds of places thought to be walkable by our professionals are not the kinds of places prioritized under current Irish zoning codes.

Items associated with being very bad for walkability appeared to address both car-oriented suburban sprawl and the dysfunctionality of some urban places. Places associated with cul-de-sac development, wide roads with multiple lanes of traffic, and long waits for pedestrians to cross streets were all seen as being bad for walkability. These attributes are very common in places typically zoned as suburban residential as they prioritize the car over the pedestrian and promote privacy. The results also implied that street engineering may shoulder part of the blame for the design of these unwalkable environments. Interestingly, places - urban or suburban - that had become dysfunctional due to higher levels of crime or the lack of proper maintenance were also perceived to be less walkable.

Most interesting from our perspective in this chapter is that the environmental design features associated with walkable vs non-walkable areas correspond to 
differences in zoning priorities. In general, surveyed professionals tended to think of walkable areas as having more of a mixed-use pedestrian-oriented village feel whereas attributes thought to discourage walkability tended to be those that dominate car-dependent zoning plans. As we shall see in the next section below, the public tended to hold similar views.

\subsection{The Population Survey of People Living in Dublin and Its Suburbs}

In addition to a web-based survey of professions The Cleaner, Greener, Leaner Study also included a comprehensive household population survey of 1064 people living in Dublin City or its suburbs. The survey was carried out from July to September 2011. With the aid of professionals who participated in the study's focus groups (see below), 16 neighborhoods or local areas were selected. From these 16 neighborhoods one adult from a total of 1064 households were interviewed. The 16 neighborhoods were identified as being either high or low in terms of walkability. The study also sought to include some neighborhoods that were categorized as being economically deprived based upon census data.

The goal was to attain respondents from a healthy mix of neighborhood types. The high walkable neighborhoods which were not deprived were historic urban communities or villages which became part of the city over time as it expanded out from its core. Two were close to the city center and two were coastal villages with good rail links to the city center. The high walkable areas which were categorized as deprived were well-known established urban neighborhoods close to the city center which had a relatively high concentration of social housing for poorer households. It was observed at the time our survey was conducted that many of these areas had started to undergo recent gentrification.

All of the low walkable neighborhood areas were suburban and car-oriented. Chosen areas that were not economically deprived were new developer-built suburban housing estates (or subdivisions), constructed in the last two decades outside the city orbital motorway. These areas are typical of the suburban sprawl which we argue is the product of a modern interpretation of zoning. The more economically deprived areas (that were also categorized as low in walkability) were local authority built social housing estates for lower income households. One of these suburban estates (or subdivisions) was completed in the 1940s and the others were built in the 1970 s to re-home residents of higher density city slums. Both of these low walkable area categories could be classified as sprawling housing estates with no definable core. While all of these suburban places were car-oriented, the economically deprived areas had some local services and public transport access possibly due to their age. The new suburban developments, however, had very little public transport or local services. In general housing tended to be built within cul-de-sacs where residents were expected to drive to attain almost all their daily needs. 
1. A variety of shops/ homes/ businesses and amenities

2. Many inviting locally owned shops

3. People about all day and in the evening shopping or visiting restaurants and pubs nearby

4. A mix of age groups, young and old people, as well as a mix of family types

5. I can do most of my shopping in local shops

6. Is an unique area with personality and character

7. Nice places within walking distance of my home, to go for a walk for recreation (such as a park or even just around the neighborhood itself)

Fig. 3 Public Opinion and the Village Construct

The population survey asked respondents a long list of questions related to their neighborhoods as well as health and travel behavior questions among others. For our purposes here, however, we focus upon just one battery of questions. Neighborhood residents were asked for their level of agreement with a series of 41 statements relating to their neighborhoods. The statements were largely similar to those in the initial professional's survey but in this case residents were asked to what degree each of these 41 attributes described the place where they lived.

A factor (component) analysis of the residents' responses to these statements reduced the statements into six sub-component groupings encompassing 38 of the statements (see Fitzsimons D’Arcy, 2013). Here we focus upon the first two components which were the most distinctive. The first component we labelled 'crime and disorder.' Further analysis showed that this component was associated with the deprivation status of the area groupings where residents were concerned about crime and the relative untidiness or run-down nature of the places they lived in. The second component we labelled 'the village' and consisted of the items listed in Fig. 3.

This second construct was more likely to be expressed by people living in walkable neighborhoods, especially areas that were better off economically. Similar to the opinions of professionals working with the built environment, the public saw walkable areas as being clearly distinctive with a "unique personality or character." As Fig. 3 suggests, residents of more walkable areas tended to see their neighborhoods as having a variety of locally owned shops, restaurants, pubs and recreational amenities "within walking distance." They also tended to believe the places they lived had a mix of age groups and family types.

\subsection{Focus Groups of Professionals Involved with the Built Environment: How Professional Participants Discussed Car-dependent vs. Walkable Areas}

Our web-based survey of professionals described above was also used to invite professionals and policy-makers to participate in a series of focus groups in the summer of 2010. Twenty-six individuals took part in five focus groups, $12 \%$ of the original webbased study sample with the same gender and age profiles as the larger group. Eight 
$(31 \%)$ of the group were from architecture, landscape architecture and urban design, six (23\%) from spatial planning, six (23\%) from transport planning and engineering, four $(15 \%)$ from public health or advocacy groups and two were public representatives $(8 \%)$.

At the beginning of each focus group, a map of the Greater Dublin Area (the city and its suburbs) was given to each participant from which they were asked to select areas of high and low walkability that were familiar to them. Open discussion followed. This format allowed for cross-comparison between groups as each discussion session had its own dynamic and direction, but usefully had a common external reference point (locations on the map). Focus groups were repeated until no new topics in relation to what makes an area walkable or not were being raised in the focus groups.

With respect to zoning, some of the most informative and insightful information was obtained from the focus group participants' narratives when describing the areas they identified as high and low walkable. While the reasons for selecting high and low walkable areas varied based on an individual's views there was little disagreement on the areas selected. Similar to the findings of the web-based survey of professionals (of which our focus groups came) and the population survey, the focus group participants tended to discuss walkable areas as being very different from car-oriented places. Again, this is important because these distinguishing differences have a great deal to do with the differences between traditional urban designs and modern zoning practices which separate uses.

So how did our focus groups participants think about neighborhoods? Interestingly, and similarly to the professional and public surveys, our focus group participants tended to think most positively about places they thought resembled walkable villages and less favorably toward modern car-dependent designs.

All of the focus groups participants agreed that highly walkable areas of Dublin tended to be centered around a village core or square or were within close proximity to the city center with small local service nodes. They also tended to suggest that such places enabled residents to attain their daily needs on foot locally. These selfcontained 'liveable' areas were seen as places where you can 'spend your weekend quite easily without going into town' [Architect] or places where 'everything is within walking distance that you could possibly need over the course of a week' [Landscape Architect]. A key characteristic of these liveable villages or neighborhoods was that they were 'built when people walked' [Transport Planner] which resulted in facilities and destinations being spaced at distances which could be walked [to]: 'Houses, shops, the church, and the pub, they are all close together. And there are a lot of houses close together. So the majority of people are able to walk everywhere... (it has) a nice villagey sort of feel to it' [Architect] and 'Parks spaced at distances that you would comfortably walk to' [Transport Planner].

Many of the focus group participants felt these desirable village-like places could exist in the city, suburb or a rural area. Within the city these urban village places were said to have their own character due to their grain, street layout, and scale and thus had a very different feel from the higher density big block city center areas. 'I suppose [the best places are like a] little village in the city in the heart of it all; you've a little ... self-sufficient village, so close to the center of the city and yet suddenly when you're in that village you sort of feel removed from the city' [Engineer]. An interesting comparison was drawn between Dalkey, a suburban coastal village just outside of 
Dublin City, and certain neighborhoods of New York City where, despite the substantially higher density differences both were discussed as being village-like and thus desirable place to live in or visit. 'When you're in New York City, you generally live in a little sort of commune, shall we call it - in the West Village, the East Village, Soho, and other nicer parts, but it's the fact that you have that close knit village in its own big city context with everything else that matters..., you still have the sea and you have nice little shops and everything is in pretty good nick so [even in New York City] it's... the fact that you have a little village, within I suppose, a bigger environment [that makes these places great places to live or visit]' [Engineer].

In comparing and contrasting walkable areas of Dublin and its suburbs with those that were perceived as car-oriented, participants overwhelming imagined walkable places as better places to live in or visit. Indeed, there appeared to be something about walkability itself that seemed to matter to them. Walkable neighborhoods were characterized as places planned or designed to facilitate walking to carry out daily needs and as places where residents could walk for recreation or leisure. 'I suppose what I would pick as high walkable are areas ... that can manage to combine both ... walking to the shops [and enabling] pleasant places [where residents can] go for a stroll' [Public Health/Advocacy]. One participant attempted to summarize his focus group's thinking about walkable areas by remarking: 'All the places that people here are saying are walkable it's [because they have] that village atmosphere. It's the sense of vibrancy and destination and something that you can actually go and do ... you can go for lunch and walk around.... and maybe head off to the seaside or up [a nearby] hill' [Urban Designer].

In addition to the notion of a village core where people could walk to attain their daily needs or to be social, focus group participants tended to also feel the best walkable places were "real places" or "unique destinations." This notion relates to the urban design concept of imageability which describes the quality of a place that makes it distinct, recognizable, and memorable (Lynch, 1965). Areas selected as high walkable were thought to be easily identified by many participants. In contrast, low walkable areas tended to be described with more difficulty without a particular identifiable place or landmark. One such area was described as: '...one of those areas that has experienced a huge amount of development in the 80s and in the 90s and [is], incoherent [as a place]. It is just a lot of housing ... with no significant facilities or character' [Spatial Planner].

It is worth noting that the professionals we interviewed as part of our web-survey and focus groups did not think that high density made places more liveable or more walkable. This is interesting because issues of density are commonly thought to be important in both transportation planning practice and walkability research (Saelens et al., 2003; Brownson et al., 2009; Ewing and Cervero, 2010). Unprompted, density was only mentioned twice in the focus groups. We suspect that while density may be important to make pedestrian-oriented, mixed-use places possible, density for density sake was not necessarily thought as critically important by our focus group participants. Instead participants frequently mentioned the scale of the built environment or the degree of its compactness - which Jan Gehl (2010, p. 65) refers to as 'the right kind of density.' 
While density was not a priority, human scale and permeability were mentioned as being important. Human scale refers to an environment scale which is perceptually comfortable for human beings in size and distance (Ewing et al., 2006; Gehl, 2010). This relative size or scale of an environment can affect feelings of comfort, belonging, isolation and vulnerability. Permeability is a measure of the ease of movement through an area. A neighborhood may have a well-connected street network but be perceived as impermeable for a variety of reasons such as the expectation that pedestrians cross wide, heavily trafficked roads or walk through dark, unkempt areas.

Scale and associated terminology was present in the vocabulary of urban designers, architects, landscape architects, planners and some of the other participants. Scale was clearly thought to affect how comfortable people felt in different types of places; comments such as 'there is a lovely scale ... the area really has nice sense of enclosure' [Urban Designer] were fairly common. Others described their emotional response to relative size or distance: 'you have a vast expanse of land in front of you ... it is very daunting' [Landscape Architect]. Those who did not use specific urban design terminology used emotional responses to convey their general comfort with places that were designed to human scale and discomfort with car-centric environments.

Car-oriented areas were typically described as lacking human scale and permeability. One participant labelled car-dependent areas as having their own type of urban form she called 'Carchitecture' [Landscape Architect]. To this participant "carchitecture scale" describes wide roads, large box buildings, long distances between services and isolated cul-de-sac suburban housing estates where the "presumption is that this is an area where homes have 2 to 3 cars' [Spatial Planner]. The wide-roads and associated large big-box developments common in these suburban places were described as being so 'enormous in scale, I feel I should be in a car' [Landscape Architect]. Similarly, large green spaces within low density housing estates (or suburban subdivisions) were also perceived as negative by participants despite the fact that access to green space is frequently mentioned as being desirable for health and wellbeing (Van den Berg et al. 2010). This is because many of the green spaces in Dublin's suburbs are not planned by landscape architects but by developers who fail to make them inviting places. Indeed, zoning for green space without providing the professional support needed to make these spaces that people want to be in can lead to the creation of some unwelcoming places. Sometimes the descriptions of these poorly designed and badly maintained green spaces were depressive: [The green space there] 'is very bleak and a lot of very open space which on the one hand makes it very permeable but at the same time makes you feel isolated' [Landscape Architect].

Participants also frequently mentioned the 'expansive' scale of the suburban road network. In all of the focus groups, blame for the negative impact of roads on walkability was attributed to transport professionals and their use of highway design standards which prioritize the movement of vehicles over people. 'They design roads to move cars quickly; they perceive [these roads] to be safer because there have less junctions, and there is no frontage, there are no driveways, and there is little pedestrian activity so the things that could potentially create a conflict are designed out' [Urban Designer]. 
Many participants also expressed concerns about the way suburban zoning regulations promoted shopping centers which were built 'completely segregated from the existing town centers' [Landscape Architect]. The difficulty in getting to them on foot or by public transport was highlighted as problematic for walkability. As one participant put it: 'most of where we are expected to shop is built around huge car parks, surrounding giant retail centers separated by wide roads and more carparks. [Even if you wanted to walk to or between these retail centers it] would require an awful lot of walking and it wouldn't be safe' [Spatial Planner]. While getting to these car-oriented shopping centers was perceived as hostile to those who wanted to arrive without a private vehicle the internal environments were described as very comfortable for walking around in. Ironically some of these malls or shopping centers were designed internally to replicate village streetscapes.

\section{Discussion and Conclusions}

This chapter makes the case that it is time to re-evaluate the way we use zoning to plan the places we live in. In large part because of the introduction of the automobile and highways, the way we use zoning to plan our communities changed during the last half of the twentieth century. Today, especially in the United States, zoning in suburban areas is being used to segregate and separate the component parts of our communities into distinct zones that are in many places only accessible if one owns and can operate a private automobile. As noted above there are growing concerns that this style of zoning is having a profoundly negative impact on our health, our sense of community and our planet.

In this chapter, we have also attempted to share some of the findings of the Dublin-based Cleaner, Greener, Leaner Study. On many levels, this study supports the notion that there are indeed different types of neighborhoods - both urban and suburban - and that the way these different types of places are zoned and planned affects how people feel and behave. Both professionals and the public clearly realize that there is a difference between modern car-dependent places and more traditional mixed-use pedestrian oriented places. And they clearly feel more positively toward the more traditional designs even though modern zoning ordinances are biased against building this traditional form of development.

Most interesting of all is that we found that when asked professionals and the public tended to have an almost innate bias in favor of places that reminded them of a village. In their mind's eye, these are distinct places where residents can easily walk to attain their daily needs or be social or to go for a pleasant walk. Perhaps this is an Irish phenomenon; we are not sure.

Still, there is something deeply appealing and human about the village concept. Therefore, we would like to propose that going forward, zoning practices be reconstructed and re-imagined to make the idea of the village a fundamental building block when planning and building the places we live. 
What we are saying is incredibly simple. We feel that planners, and engineers and developers must be taught and expected to build villages again. These villages can be in urban places, suburban places and rural places. Some will include high-rise buildings, or modern architecture and others might make some accommodation for the automobile. But the key is that these places should be first and foremost about building more walkable places that enable community connections and break the dependency on the automobile. In too many places current zoning practices require planners, engineers and developers to think first about cars and how to move them and park them; they are also expected to think first and foremost about separating uses. We are asking for a very different starting point. We are asking for one that first asks to consider people, and their connections with each other, and their connections with the communities they live in.

Our call to think more about, and to plan more around, the village concept is only unique in its simplicity. There is already an important and sophisticated movement or researchers and practitioners who are currently advocating that we plan and build more people oriented, liveable or sustainable communities again (Frank and Engelke, 2001; King et al., 2002; Sallis et al., 2009). This movement has many strands that include new urbanism (Duany et al., 2000; Duany \& Talen, 2002), Jan Gehl's call to build Cities for People (2010), models that advocate the building of Transit-Oriented Development (Bernick \& Cervero, 1997; Cervero, 1998, 2004; Ewing et al., 2013) and discussions about the key ingredients to building more human places usually involving a focus upon density, diversity (of land-use mix), design, destination accessibility and distance to transport (Cervero, 1998; Ewing \& Cervero, 2010; Giles-Corti et al., 2016). Others have focused more on placemaking (e.g., Walters, 2007; Brown et al., 2009) retrofitting car-oriented suburban into more liveable places (Dunham-Jones and Williamson, 2008); health (Saelens et al., 2003); happiness (Leyden et al., 2011; Montgomery, 2013; and Pfeiffer and Cloutier, 2016); or sustainability. In Ireland, change is beginning to happen in that exceptions to current suburban zoning laws can now be sought; as a result several Transit-Oriented villages are being completed or proposed. The national government is also beginning to promote improved mixed-use street designs that hold great promise. The recent introduction of mandatory guidelines in the Design Manual for Urban Roads and Streets (Department for Transport Tourism and Sport [DTTAS] and Department for Environment Community and Local Government [DECLG], 2013) with multi-disciplinary inputs based on the UK's Manual for Streets (Department for Transport UK, 2007) has facilitated this.

Early in the Cleaner, Leaner, Greener Study it became apparent that many design considerations and concepts can get lost in translation among multidisciplinary teams. This became especially evident in the focus groups when participants who were not from the design professions started to turn to designers to verbalize what they were trying to describe. Similarly, mistranslations can happen when practitioners try to apply academic research, or when academics propose ideas that do not have the grounded knowledge that comes from real world design practice. Design and research teams need words and concepts that people can easily identify with across disciplines and professions; complicated academic language can often miss the mark. We feel that asking those who are expected to plan and build our communi- 
ties to think and plan around the concept of the village may provide a useful starting point for many. It is certainly a better starting point than assuming that new suburban areas should be built around the automobile, wide roads, and shopping malls.

We sincerely hope that going forward zoning practices take heed of the important insights advocates for more vibrant communities envision. And we hope that once again people have more opportunities to live in the kinds of environments that enable human beings to flourish.

\section{References}

Baxandall, R. F., \& Ewen, E. (2000). Picture windows: How the suburbs happened. New York: Basic Books.

Bernick, M., \& Cervero, R. (1997). Transit villages in the 21st century. New York: McGraw-Hill.

Brown, L. J., Dixon, D., \& Gillham, O. (2009). Urban design for an urban century: Placemaking for people. Hoboken, NJ: Wiley.

Brownson, R. C., Hoehner, C. M., Day, K., Forsyth, A., \& Sallis, J. F. (2009). Measuring the built environment for physical activity: State of the science. American Journal of Preventive Medicine, 36(4 Suppl), 99-123. https://doi.org/10.1016/j.amepre.2009.01.005.

Centers for Disease Control and Prevention. (2017). CDC Vital signs motor vehicle crash deaths. Vital signs. Retrieved June 8, 2017, from https://www.cdc.gov/vitalsigns/motor-vehicle-safety/

Cervero, R. (1998). The transit metropolis: A global inquiry. Washington, DC: Island press.

Cervero, R. (2004). Transit-oriented development in the United States: Experiences, challenges, and prospects (Vol. 102). Washington, DC: Transportation Research Board.

De Nazelle, A., Nieuwenhuijsen, M. J., Antó, J. M., Brauer, M., Briggs, D., Braun-Fahrlander, C., \& Hoek, G. (2011). Improving health through policies that promote active travel: A review of evidence to support integrated health impact assessment. Environment International, 37(4), 766-777.

Department for Transport Tourism and Sport (DTTAS), \& Department for Environment Community and Local Government (DECLG). (2013). Design manual for urban roads and streets. Dublin, Ireland: Author.

Department for Transport UK. (2007). Manual for streets. London: Thomas Telford.

Duany, A., Plater-Zyberk, E., \& Speck, J. (2000). Suburban nation. New York: North Point Press.

Duany, A., \& Talen, E. (2002). Transect planning. Journal of the American Planning Association, 68(3), 245-266.

Dunham-Jones, E., \& Williamson, J. (2008). Retrofitting suburbia: Urban design solutions for redesigning suburbs. New York: John Wiley \& Sons.

Edwards, P., \& Tsouros, A. (2006). Promoting physical activity and active living in urban environments. The role of local governments. Copenhagen, Denmark: WHO (World Health Organization) Regional Office for Europe. Retrieved from http://www.euro.who.int/_data/ assets/pdf_file/0009/98424/E89498.pdf.

Ewing, R., Bartholomew, K., Burden, D., Zimmerman, S., \& Brown, L. (2013). Pedestrian \& transit-Oriented design (1st ed.). Washington, DC: Urban Land Institute and American Planning Association.

Ewing, R., \& Cervero, R. (2010). Travel and the built environment: A meta-analysis. Journal of the American Planning Association, 76(3), 265-294.

Ewing, R., Handy, S. L., Brownson, R. C., Clemente, O., \& Winston, E. (2006). Identifying and measuring urban design qualities related to walkability. Journal of Physical Activity and Health, 3(Suppl 1), S223-S239.

Fitzsimons D'Arcy, L. (2013). A multidisciplinary examination of walkability: Its concept, assessment and applicability. Dublin: Dublin City University.

Florida, R. (2005). Cities and the creative class. New York: Routledge. 
Florida, R. (2010). Who's your City?: How the creative economy is making where to live the most important decision of your life. Toronto: Vintage Canada.

Frank, L. D., \& Engelke, P. O. (2001). The built environment and human activity patterns: Exploring the impacts of urban form on public health. Journal of Planning Literature, 16(2), 202-218. https://doi.org/10.1177/08854120122093339.

Frank, L. D., Sallis, J. F., Conway, T. L., Chapman, J. E., Saelens, B. E., \& Bachman, W. (2006). Many pathways from land use to health: Associations between neighborhood walkability and active transportation, body mass index, and air quality. Journal of the American Planning Association, 72(1), 75-87.

Frank, L. D., Kerr, J., Sallis, J. F., Miles, R., \& Chapman, J. (2008). A hierarchy of Sociodemographic and environmental correlates of walking and obesity. Preventive Medicine, 47(2), 172-178. https://doi.org/10.1016/j.ypmed.2008.04.004.

Frumkin, H., Frank, L. D., \& Jackson, R. J. (2004). Urban sprawl and public health (1st ed.). Washington, DC: Island Press.

Gallagher, A. (2017). New homes with old fashioned values in D24. The Irish Times. Retrieved from http://www.irishtimes.com/life-and-style/homes-and-property/new-to-market/new-homeswith-old-fashioned-values-in-d24-from-295-000-1.3035373.

Gehl, J. (2010). Cities for people (1st ed.). London: Island Press.

Giles-Corti, B., Vernez-Moudon, A., Reis, R., Turrell, G., Dannenberg, A. L., Badland, H., et al. (2016). City planning and population health: A global challenge. The Lancet, 388(10062), 2912-2924. doi:10.1016/S0140-6736(16)30066-6.

Glaeser, E. L., \& Kahn, M. E. (2010). The greenness of cities: Carbon dioxide emissions and urban development. Journal of Urban Economics, 67(3), 404-418.

Glaeser, E. (2011). Triumph of the City: How our greatest invention makes us richer, smarter, greener, healthier, and happier. New York: Penguin.

Goldberg, A., Leyden, K. M., \& Scotto, T. J. (2012). Untangling what makes cities Liveable: Happiness in five cities. Proceedings of the Institution of Civil Engineers-Urban Design and Planning, 165(3), 127-136.

Haas, T. (2008). New urbanism and beyond: Designing cities for the future. New York: Rizzoli.

Hogan, M. J., Leyden, K. M., Conway, R., Goldberg, A., Walsh, D., \& McKenna-Plumley, P. E. (2016). Happiness and health across the lifespan in five major cities: The impact of place and government performance. Social Science \& Medicine, 162, 168-176.

Jackson, R. J., Dannenberg, A. L., \& Frumkin, H. (2013). Health and the built environment: 10 years after. American Journal of Public Health, 103(9), 1542-1544. https://doi.org/10.2105/ AJPH.2013.301482.

Kahn, M. E. (2007). Green cities: Urban growth and the environment. Washington, DC: Brookings Institution Press.

Kay, J. H. (1997). Asphalt nation: How the automobile took over America, and how we can take it back. New York: University of California Press.

King, A. C., Stokols, D., Talen, E., Brassington, G. S., \& Killingsworth, R. (2002). Theoretical approaches to the promotion of physical activity forging a Transdisciplinary paradigm. American Journal of Preventive Medicine, 23(2S), 15-25.

Lee, I. M., Shiroma, E. J., Lobelo, F., Puska, P., Blair, S. N., \& Katzmarzyk, P. T. (2012). Effect of physical inactivity on major non-communicable diseases worldwide: An analysis of burden of disease and life expectancy. Lancet, 380(9838), 219-229. doi:10.1016/S0140-6736(12)61031-9.

Leinberger, C. B. (2012, May 27). Now coveted: A walkable, convenient place. New York Times sunday review the opinion pages. Retrieved from http://ctmainstreet.org/wp-content/ uploads/2012/07/1a-Opinion-Walkable-Place.pdf

Leyden, K. M. (2003). Social capital and the built environment: The importance of Walkable neighborhoods. American Journal of Public Health, 93(9), 1546-1551.

Leyden, K. M., Goldberg, A., \& Michelbach, P. (2011). Understanding the pursuit of happiness in ten major cities. Urban Affairs Review, 47(6), 861-888.

Levine, J. (2010). Zoned out: Regulation, markets, and choices in transportation and metropolitan land use. New York: Routledge. 
Lovasi, G. S., Neckerman, K. M., Quinn, J. W., Weiss, C. C., \& Rundle, A. (2009). Effect of individual or neighborhood disadvantage on the association between neighborhood walkability and body mass index. American Journal of Public Health, 99(2), 279-284.

Lynch, K. (1965). Image of the City (2nd ed.). London: MIT Press.

McKenzie, E. (1994). Privatopia: Homeowner associations and the rise of residential private government. New Haven: Yale University Press.

Montgomery, C. (2013). Happy city: transforming our lives through urban design. Macmillan.

Morris, J. N., \& Hardman, A. E. (1997). Walking to health. Sports Medicine, 23(5), 306-332.

Pfeiffer, D., \& Cloutier, S. (2016). Planning for happy neighborhoods. Journal of the American Planning Association, 82(3), 267-279.

Saelens, B. E., Sallis, J. F., Black, J. B., \& Chen, D. (2003). Neighborhood-based differences in physical activity: An environment scale evaluation. American Journal of Public Health, 93(9), $1552-1558$.

Sallis, J. F., Bauman, A., \& Pratt, M. (1998). Environmental and policy interventions to promote physical activity. American Journal of Preventive Medicine, 15(4), 379-397.

Sallis, J. F., Saelens, B. E., Frank, L. D., Conway, T. L., Slymen, D. J., Cain, K. L., et al. (2009). Neighborhood built environment and income: Examining multiple health outcomes. Social Science \& Medicine, 68(7), 1285-1293.

Schwieterman, J. P., \& Caspall, D. M. (2006). The politics of place: A history of zoning in Chicago. Chicago, IL: Lake Claremont Press.

Southworth, M., \& Ben-Joseph, E. (1995). Street standards and the shaping of suburbia. Journal of the American Planning Association, 61(1), 65-81.

U.S. Department of Health and Human Services: Centers for Disease Control and Prevention: National Centre for Chronic Disease Prevention and Health Promotion. (1996). Physical activity and health: A report of the surgeon general. Atlanta, GA: Author. Retrieved from http:// www.cdc.gov/nccdphp/sgr/pdf/sgrfull.pdf.

Van den Berg, A. E., Maas, J., Verheij, R. A., \& Groenewegen, P. P. (2010). Green space as a buffer between stressful life events and health. Social Science and Medicine, 70(8), 1203-1210. https://doi.org/10.1016/j.socscimed.2010.01.002.

Walters, D. R. (2007). Designing community: Charrettes, master plans and form-based codes. London: Routledge.

Warburton, D. E. R., Nicol, C. W., \& Bredin, S. S. D. (2006). Health benefits of physical activity: The evidence. Canadian Medical Association Journal, 174(6), 801-809.

WHO. (2017). World Health Organization Global Health Observatory data, road traffic deaths. Retrieved June 8, 2017, from http://www.who.int/gho/road_safety/mortality/en/

WHO Regional Office for Europe. (2006). Physical activity and health in Europe: Evidence for action. Copenhagen: Author. Retrieved from http://www.euro.who.int/_data/assets/pdf_ file/0011/87545/E89490.pdf.

Wickham, J. (2006). Gridlock: Dublin's transport crisis and the future of the City (1st ed.). Dublin: New Island. 